Jpn. J. Pharm. Health Care Sci.

\title{
昭和大学藤が丘病院におけるリネゾリド使用状況
}

田中広紀 ${ }^{* 12}$, 平林麻里 ${ }^{12}$, 並木美加子 ${ }^{1,2}$, 宇賀神和久 ${ }^{1,3}$, 丸茂健治 ${ }^{1,4}$, 川野留美子 ${ }^{1,5}$, 田口和三 ${ }^{1,4}$, 菊池敏樹 ${ }^{1,6}$, 長島梧郎 ${ }^{1,7}$ 昭和大学藤が丘病院感染対策室 ${ }^{1}$, 同薬局 ${ }^{2}$, 同中央検査部 ${ }^{3}$, 同臨床病理科 ${ }^{4}$, 同看護部 ${ }^{5}$, 同内科呼吸器 ${ }^{6}$, 同脳神経外科 ${ }^{7}$

\section{Evaluation of Linezolid for Patients with MRSA Infection in Showa University Fujigaoka Hospital}

Hironori Tanaka ${ }^{* 12}$, Mari Hirabayashi ${ }^{12}$, Mikako Namiki $^{12}$, Kazuhisa Ugajin $^{1,3}$, Kenji Marumo ${ }^{14}$, Rumiko Kawano ${ }^{1,5}$, Kazumi Taguchi ${ }^{1,4}$, Toshiki Kikuchi ${ }^{1,6}$ and Goro Nagashima ${ }^{1,7}$

Division of Infection Control ${ }^{1}$, Division of Pharmacy ${ }^{2}$, Division of Central Laboratory ${ }^{3}$, Department of Clinical Pathology, Division of Nursing ${ }^{5}$, Department of Respiratory Medicine ${ }^{6}$, Department of Neurosurgery ${ }^{7}$, Showa University Fujigaoka Hospital

\author{
Received A pril 25, 2008 \\ A ccepted September 4, 2008
}

In Japan, linezolid (LZD) was approved as a new agent for methicillin-resistant Staphylococcus aureus (MRSA) infection in A pril 2006, and its proper use is strongly recommended for preventing the occurrence of MRSA. In this study, we evaluated the efficacy of LZD in patients with MRSA infection who had been admitted to our hospital from A pril 2006 to March 2007. LZD was administered to 32 patients (sepsis: 14 cases; pneumonia: 11 cases; wound infection : 7 cases) for $12.8 \pm$ 8.4 days (mean \pm standard deviation). Improper use was noted in 4 patients.

LZD proved excellent as regards transfer from blood to lung tissue in patients with MRSA infection. Thrombocytopenia is a major known adverse reaction of LZD and was observed in 6 patients, but they recovered as soon as LZD was withdrawn. Criteria for the administration of LZD will be of great value in ensuring the proper use of LZD as an anti-MRSA agent as well as in hospital infection control measures against MRSA.

Key words — linezolid, MRSA, efficacy, thrombocytopenia

緒言

linezolid(LZD)は, オキサゾリジノン系に分類される 新規合成抗菌剂であり，既存の抗菌薬に対して耐性を示 すグラム陽性球菌に対しても抗菌力を有している．すで に欧米では臨床使用されており，光の有効性は高く評価 されている ${ }^{12)}$.わが国においても，2001年に vancomycin-resistant Enterococcus (VRE)治療薬として，2006年 4 月からは methicillin-resistant Staphylococus aureus(MRSA) が適応菌種として追加になり，臨床使用が拡大した．昭 和大学藤が丘病院(以下, 当院と略す)では, VRE 治療薬 としてLZD を採用していたが, MRSA の追加適応とな
るまで使用例はなかった．LZD は数少ないVRE 治療薬 であること，また，経口刘もあることから，乱用による 耐性菌発生の危険性を考慮し, 適正使用が強く望まれて いる薬斉である.抗 MRSA 薬使用の手引き(http : / / www. kansensho.or.jp/news/pdf/mrsa_tebiki.pdf)でも，敗血症， 院内肺炎, 皮膚・軟部組織感染症, 腹腔内膿瘍, 膿胸な どの重症感染症や，腎機能障害患者に対して選択される 場合があるという記載があり，VRE 用薬ということも 踏まえて，より慎重な使用が望まれる薬剂となってい る.当院では LZD 使用は届出制としている .この中で 当院における LZD 使用状況と炎の評価を行ったので報 告する. 


\section{方法}

2006 年 4 月から 2007 年 3 月までにMRSA に対する LZD 注使用症例を対象とし，有効率と適正使用につい て評価した。体温, 白血球(WBC)，C反応性タンパク (CRP)，へモグロビン(Hgb)，血小板(PLT)，尿素窒素 $(B U N)$, 血清クレアチニン(CRE)への LZD の影響に対す る評価は，Wilcoxon signed-rank 検定を用いた . LZD の MRSA 適応取得前後 1 年の抗 MRSA 薬の使用量(バイア ル数)を月別に集計し， Student- $T$ 検定を行った．いずれ も $\mathrm{p}<0.05$ を有意差ありとした .

\section{結果}

LZD の MRSA 追加適応前後 1年間の抗 MRSA 薬の推 移と使用量を示した(図 1). 月別平均使用量(使用本数士

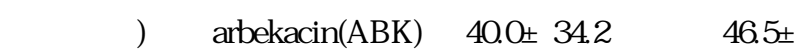

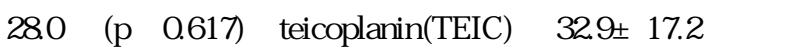
$51.4 \pm 33.8$ 本 $(p=0.126)$, vancomycin (VCM) で $447.2 \pm$

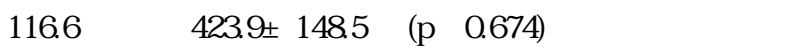
抗 MRSA 薬使用量は有意に变化しておらず，特にLZD に偏った使用状況には至っていなかった . 対象症例 32 例(男性 29 例，女性 3例)の内訳は, 敗血症 14 例, 肺炎 11 例，創感染 7 例で, 平均年齢 $69.8 \pm 6.6$ 歳, LZD 投与 平均日数は $12.8 \pm 8.4$ 日であつた(表 1$)$. 疾患別転帰は敗 血症で 14例中 8 例生存 $(57 \%)$, 肺炎で 11 例中 10 例生 存 $(91 \%)$ ，創感染で 7例中 6例生存(86\%)であった(表 1)．
生存例における LZD 第一選択の割合は, 肺炎で 10 例中 9例(90\%)と高かった(表 1)．LZD 投与前後における体 温, WBC , CRP , Hgb , PLT, BUN , CRE の変化を示し た(表 2) . 体温は $38.2 \pm 0.8^{\circ} \mathrm{C}$ から $37.3 \pm 0.8^{\circ} \mathrm{C}(\mathrm{P}<0.001)$ CRPは $9.4 \pm 7.3 \mathrm{mg} / \mathrm{dL}$ から $6.7 \pm 5.5 \mathrm{mg} / \mathrm{dL}(\mathrm{P}=0.032)$,

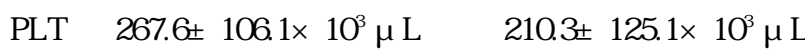
$(P=0.007)$ のみが有意に減少した。PLT に関して，LZD 使用前に正常範囲内であったものが，使用開始後半減も

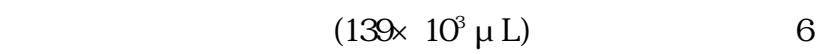
例で , このときの使用日数を調査した . 投与平均日数は 13.5日(範囲，7日〜18日)であった ここの6例は，PLT がすべて最低となった日に LZD 投与を中止しており， 光の後, 全例で正常範囲内に回復した. LZD 投与前後 のPLT 減少率と投与日数の関係を示した(図 2). 増加例 もあったが，投与日数の長期化に伴いPLT も減少する 傾向か認められた $(R=0.525)$.

当院での LZD 投与基準は, 細菌検査でMRSA または VRE が検出されていることを必須とし，他剤で無効 例, 人工呼吸器関連肺炎を含む重症感染症, 重症腎機能 障害患者 $(\mathrm{CRE}>2.5 \mathrm{mg} / \mathrm{dL})$ もしくは腎不全進行例，他剂 でアレルギーのある患者のいずれかを満たした症例とし ている.この投与基準に合致していたか調査を行った . LZD 投与が不適切と判断された症例は 32 例中 4 例(13 \%)であった . 臨床上 , LZD が有効であった MRSA 敗血 症の1例を示す(図 3)

症例：60代男性, 大動脈弁輪拡張症のため手術(Bentall Operation)を施行した. 手術後18病日に発熱しVCM +

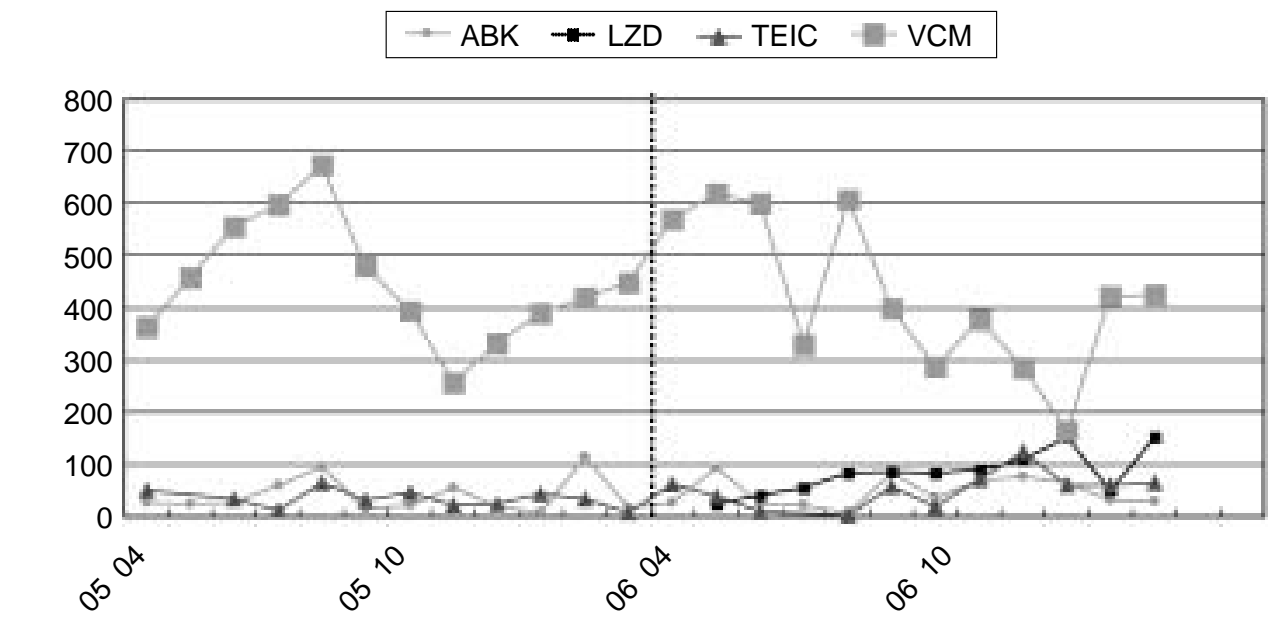

抗 MRSA 薬の使用量の比較

\begin{tabular}{|c|c|c|c|}
\hline & 前 & 後 & $p$ 値( $\mathrm{t}$-test $)$ \\
\hline \hline ABK & $40.0 \pm 34.2$ & $46.5 \pm 28.0$ & 0.617 \\
\hline TEIC & $32.9 \pm 17.2$ & $51.4 \pm 33.8$ & 0.126 \\
\hline VCM & $447.2 \pm 116.6$ & $423.9 \pm 148.5$ & 0.674 \\
\hline
\end{tabular}

単位: 平均本数士標準偏差

図 1. 抗 MRSA 薬使用量の推移 
表 1 . 患者背景と疾患別転帰，LZD 第一選択の割合 患者背景と疾患別の割合

\begin{tabular}{|c|c|}
\hline 平均年齢 & $69.8 \pm 6.6$ 歳 \\
\hline 男/女 & $29 / 3$ \\
\hline 平均投与日数 & $12.8 \pm 8.4$ 日 \\
\hline
\end{tabular}

\begin{tabular}{|c|c|}
\hline 病名 & 症例数(\%) \\
\hline 敗血症 & $14(44)$ \\
\hline 肺炎 & $11(34)$ \\
\hline 創感染 & $7(22)$ \\
\hline
\end{tabular}

疾患別転帰と生存例の LZD 第一選択の割合

\begin{tabular}{|c|c|c|}
\hline & 生存/死亡 & 第一選択(\%) \\
\hline 敗血症 & $8 / 6$ & $4(50)$ \\
\hline 肺炎 & $10 / 1$ & $9(90)$ \\
\hline 創感染 $*$ & $6 / 1$ & $3(50)$ \\
\hline
\end{tabular}

※縦隔炎, 腹腔内膿瘍, 創感染を含む

表 2 . 体温，検査值に対する LZD 投与の影響

\begin{tabular}{|c|c|c|c|}
\hline & 前 & 後 & $\mathrm{p}$ value \\
\hline 熱 $\left({ }^{\circ} \mathrm{C}\right)$ & $38.2 \pm 0.8$ & $37.3 \pm 0.8$ & $<0.001^{* * *}$ \\
\hline $\mathrm{WBC}\left(\times 10^{3} / \mathrm{mm}^{3}\right)$ & $12.6 \pm 5.8$ & $11.8 \pm 9.3$ & 0.169 \\
\hline $\mathrm{CRP}(\mathrm{mg} / \mathrm{dL})$ & $9.4 \pm 7.3$ & $6.7 \pm 5.5$ & $0.032^{*}$ \\
\hline $\mathrm{BUN}(\mathrm{mg} / \mathrm{dL})$ & $35.1 \pm 20.7$ & $34.4 \pm 23.7$ & 0.814 \\
\hline $\mathrm{CRE}(\mathrm{mg} / \mathrm{dL})$ & $2.3 \pm 2.3$ & $2.0 \pm 1.8$ & 0.193 \\
\hline $\mathrm{Hgb}(\mathrm{g} / \mathrm{dL})$ & $9.5 \pm 2.0$ & $9.1 \pm 2.1$ & 0.225 \\
\hline $\mathrm{PLT}\left(\times 10^{3} / \mu \mathrm{L}\right)$ & $267.6 \pm 106.1$ & $210.3 \pm 125.1$ & $0.007^{* *}$ \\
\hline \multicolumn{4}{|c}{${ }^{* *} ; \mathrm{p}<0.001,{ }^{*} ; \mathrm{p}<0.01,{ }^{*} ; \mathrm{p}<0.05$}
\end{tabular}

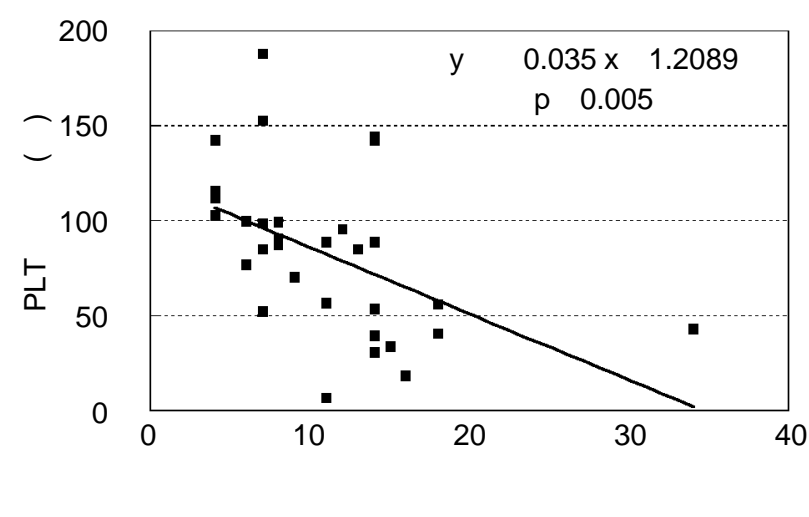

図 2 . 血小板減少率と LZD 投与日数

imipenem/cilastatin(IPM/CS)の投与を開始した . 血液培 養から MRSA が検出され，MRSA 敗血症と診断された。 VCM の血中濃度を測定し，ピーク值 $18.5 \mathrm{~m} / \mathrm{mL}$ ，卜ラ

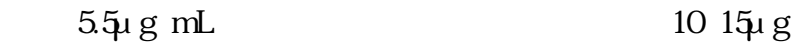
$\mathrm{mL}$ 付近において, Therapeutic Drug Monitoring(TDM)を
行い,VCM 1.5g/回/日に増量した. 1 週間後に再度血 液培養と血中濃度を測定したところ, トラフ值は 11.8 $\mu \mathrm{g} / \mathrm{mL}$ あったが, 血液中から再度 MRSA が検出され た、発熱が継続していたこと，重症例であること，人工 血管感染が強く疑われること, カテーテル類はすでに抜 去れていること，VCM の増量に伴う腎障害を考慮に入 れ，LZD 1,200 mg/日を開始した . LZD 投与開始から WBC，CRP，熱が低下し，18日の投与で解熱，PLTが 低下傾向で $123 \times 10^{3} / \mathrm{mL}$ まで減少したが, 有効と判断 し，投与終了となった．

\section{考察}

近年, 院内感染を引き起こす多くの細菌が多斉耐性化 しつつある.MRSA は关の主要な原因菌で, わが国で は 20 年以上にわたり，院内感染の主役となっている . 当院でも LZD は第 4 番目の抗 MRSA 薬として認可され たが, 他の 3斉に比べてTDM を行わずに使用できるこ と, 腎機能低下時にも用量調節の必要がないことから安 易に使用される懸念があった . LZD の適応菌種として MRSA が追加されたのを契機に，LZD の適応と注意点 を記載した回覧を感染対策室から配布，抗菌薬使用届の 対象とし，原則として infection control team(ICT)におい て，症例報告とし適正使用に努めている。緊急使用時に さまざまな手続きでLZD 使用の契機を失わないよう， 当院ではあえて LZD を許可制にはしていない，今回の 調査では 8割以上が適正に使用されていた . しかし, 不 適切と思われる使用もあり，LZD は他の抗 MRSA 薬が 無効な場合に使用する(抗 MRSA 薬使用の手引き http : //www.kansensho.or.jp/news/pdf/mrsa_tebiki.pdf)といj 位置付けからも，今後も使用の際には注意が必要であ る．血液毒性に関するA Attassi3)らの報告では，LZD によ る PLT 減少や貧血は投与期間に依存しており，PLT に 関しては比較的早期から低下していた . 当院での LZD 投与例でも $\mathrm{PLT}$ に関しては投与継続の重要な因子で あった . 今後，LZD がさまざまな診療科で使用される ことを考慮すると，抗癌剂のように，PLT 数による投 与可否の指標や定期的な検査を義務付けることも検討し ており，出血傾向が疑われる患者，抗癌斉投与による血 小板低下が起こる可能性がある患者には，より慎重に投 与をすべきであると考える．Brier らの報告と同樣(゙)， LZD 投与による腎機能への影響については, 当院の投 与例でも投与前後で有意な悪化は認められなかった . 肺 炎に関しては高い有効性が得られ，第一選択で使用され ている割合が高かった．人工呼吸器関連肺炎に使用した 例もあり，肺組織への LZD の良好な移行性5が有効性に 関与していたと推察される.MRSA 肺炎と診断された 生存率においてはVCM を上回る LZD の有用性がすで 

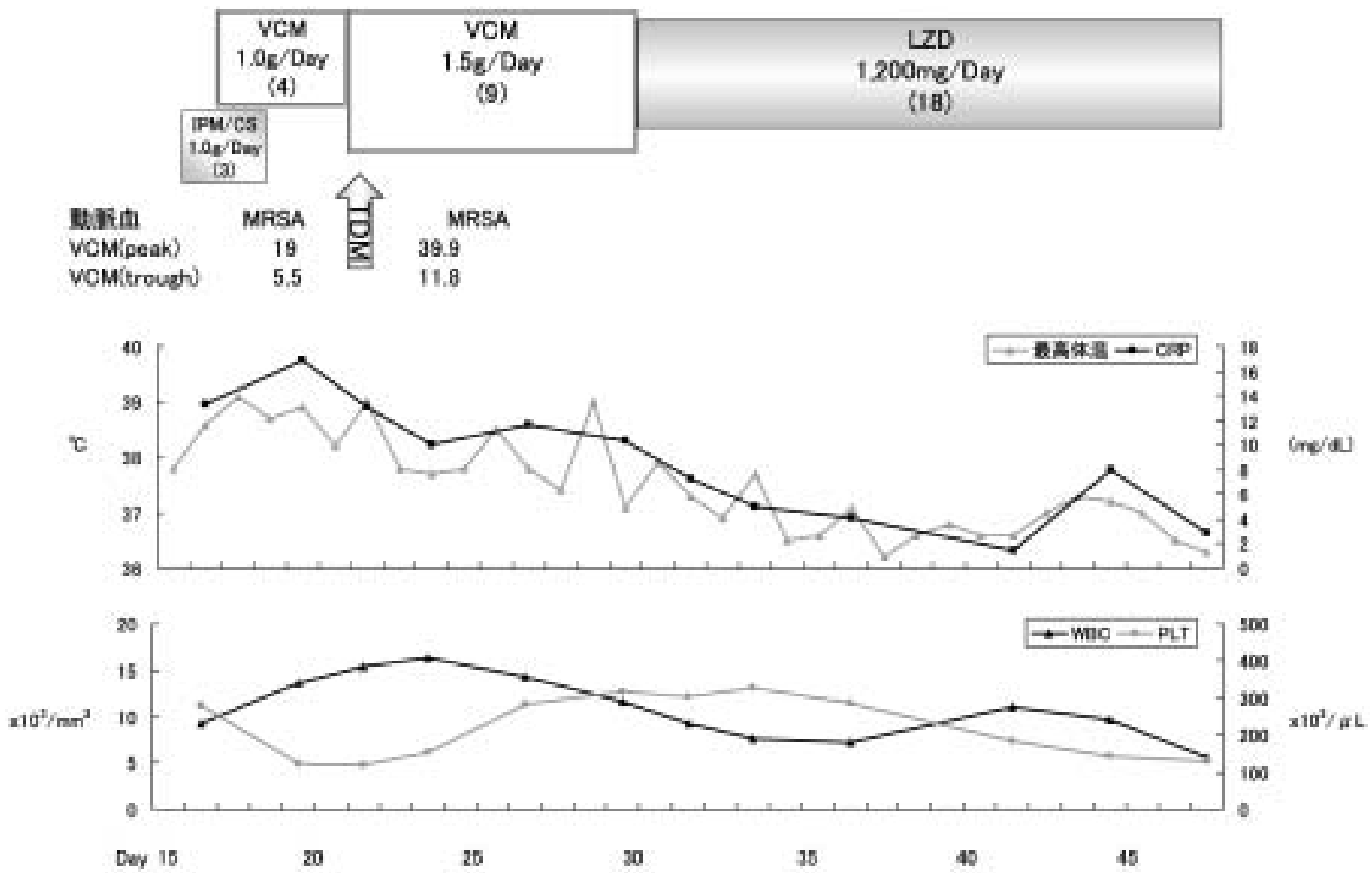

図 3.臨床上 LZD が有効であった症例

に報告されている11.当院では，まだ症例が少ないため， さらなる評価が必要であるが，MRSA 肺炎と確定診断 された際のLZD の有用性は高いことが予想される．今 回提示した症例は，初期治療としてVCM で治療を開始 した．欧米では，近年 S. aureusに対するVCM 感受性 が低下しておりの),Tenover らが示すように VCM の minimum inhibitory concentration(MIC)が $4 \mathrm{\mu g} / \mathrm{mL}$ を越えると VCM による治療の有効性が低下することが報告されて いる7゙.しかし，今回提示した症例では，VCM と LZD の MIC はいずれも $4 \mathrm{rg} / \mathrm{mL}$ を下回っており，VCM と作用 機序の異なる LZD に切り替えたことで有効性が認めら れた .すでにわが国においても，LZD が有効であった MRSA 感染症についての報告がなされている8-12)．TDM を積極的に行うことで，抗 MRSA 薬の有効性，安全性 を確保し効果判定を的確に行い，LZD 投与を規制する のではなく，重症例，特に肺炎・敗血症例や薬剤移行性 が悪く生命に危険のある症例，適切な゙治療開始 72-96 時 間後で改善しない症例等や腎不全急性増悪例，他斉無効 例やアレルギー症例などでは, LZD の絶対適応となる ことから ${ }^{13}$ 早い段階に積極的に使用することも有用であ ると考える.残念ながら，LZD も他の抗 MRSA 薬と同 樣に，MRSA に対してはすでに耐性株が存在する ${ }^{14)}$.し たがって，LZD 使用には対象症例の見極めと抗 MRSA 薬使用の手引き(http : / / www.kansensho.or.jp/news/pdf/ mrsa_tebiki.pdf)に沿った適正使用が望まれる. 現在当院
で行っているLZD 適正使用のための他の試みとして は，抗 MRSA 薬使用の手引きの紹介や 4 剂ある薬刘の 特徵，使用状況も踏まえたセミナーなどの教育，LZD の MIC を測定，耐性についての細菌学的な面からの監 視を行っている．また，毎週行っているICT ラウンド の際に抗 MRSA 薬使用患者一覧を作成，確認を行い， 治療であるか，予防投与であるかも含めて検討を行い， 必要であれば介入を行うことでVRE の発生予防も含め た適正使用に勤めている . 抗 MRSA 薬に関しては，ICT 担当薬阁師が日々使用患者についてのチェックを行い， 投与量，TDM の推奨を行っている. 通常行っている MRSA 感染対策予防はもちろんのこと,さまざまな感 染対策の一環として貴重な LZD を耐性化によって失わ ないためにも，今後も使用状況の把握と評価を引き続き 行い適正使用を推進しなければならない．MRSA 院内 感染制御および LZD 而性化防止の立場から，LZD 使用 時にはICT による介入も必要であると考えている．

\section{引用文献}

1) R.G. Wunderink, J. Rello, S.K. Cammarata, R.V. Croos Dabrera, M.H. Kollef, Linezolid vs vancomycin : analysis of two double-blind studies of patients with methicillin-resistant Staphylococcus aureus nosocomial pneumonia, Chest, 124 , 1789-1797 (2003). 
2) J.A. Cepeda, T. Whitehouse, B. Cooper, J. Hails, K. Jones, F. Kwaku, L. Taylor, S. Hayman, S. Shaw, C. Kibbler, R. Shulman, M. Singer, S.P. Wilson, Linezolid versus teicoplanin in the treatment of Gram-positive infections in the critically ill : a randomized, doubleblind, multicentre study, J. Antimicrob. Chemother., 53 , 345-355 (2004).

3) K. Attassi, E. Hershberger, R. Alam, M.J. Zervos. Thrombocytopenia associated with linezolid therapy, Clin. Infect. Dis., 34 , 695-698 (2002).

4) M.E. Brier, D.J. Stalker, G.R. A ronoff, D.H. Batts, K. K. Ryan, M. O'Grady, N.K. Hopkins, G.L. Jungbluth, Pharmacokinetics of linezolid in subjects with renal dysfunction, Antimicrob. Agents. Chemother., 47 , 2775-2780 (2003).

5) J.E. Jr. Conte, J.A. Golden, J. Kipps, E. Zurlinden, Intrapulmonary pharmacokinetics of linezolid, Antimicrob. Agents. Chemother., 46 , 1475-1480 (2002).

6) F.C. Tenover, J.W. Biddle, M.V. Lancaster, Increasing resistance to vancomycin and other glycopeptides in Staphylococcus aureus, Emerg. Infect. Dis., 7 ,327-332 (2001).

7) S.K. Fridkin, J. Hageman, L.K. McDougal, J. Mohammed, W.R. Jarvis, T.M. Perl, F.C. Tenover, for the Vancomycin-Intermediate Staphylococcus aureus Epidemiology Study Group, Epidemiological and Microbiological Characterization of Infections Caused by Staphylococcus aureus with Reduced Susceptibility to V ancomycin, United States, 1997-2001, Clin. Infect.
Dis., 36 , 429-439 (2003).

8) 坂本晋, 本間栄, 中谷龍王, 川畑雅照, 岸一馬, 坪 井永保, 成井浩司, 五十嵐正博, 林昌洋, 中田紘一 郎，吉村邦彦，V ancomycin 無効で linezolid が奏効 したMRSA 敗血症の1例，日本化学療法学会杂倠志， $51,579-582$ (2003).

9) 大河内眞也, 五味和紀, 德江豊, 菊地利明, 藤村 茂，貫和敏博，渡辺彰，Linezolidにより救命しえ たMRSA 敗血症の1例, 日本化学療法学会杂隹誌, 52, 787-792 (2004).

10) 生天目信之, 白井良夫, 畠山勝義, 加藤清, MRSA (メチシリン耐性黄色ブドウ球菌)敗血症に対し line zolid(ZYVOX)が著効した 1例，新潟医学会杂倠誌， $118,171-174$ (2004).

11）番場竹生, 若井俊文, 白井良夫, 横山直行, 畠山勝 義，胆管癌術後のMRSA 肺炎及びEnterococcusに よる腹腔内感染に対し linezolid が著効した 1例，新 潟医学会杂隹誌，118，154-156 (2004).

12) 福田雄一, 柳原克紀, 河野茂, MRSA 感染症でリ ネゾリド治療が有効であった症例, 治療学, 40 , 214-218 (2006).

13) 橋本章司, 抗菌薬使用のエビデンス 抗 MRSA 薬 をどう使い分けるか？，EBM ジャーナル，9，344349 (2008).

14) S. Tsiodras, H.S. Gold, G. Sakoulas, G.M. Eliopoulos, C. Wennersten, L. V enkataraman, R.C. Moellering, M. J. Ferraro, Linezolid resistance in a clinical isolate of Staphylococcus aureus, Lancet, 21 , 207-208 (2001). 